\title{
Hygrothermal implications of low and zero energy standards for building envelope performance in the UK
}

\begin{abstract}
Driven by Climate Change legislation and high rates of fuel poverty, the UK faces multiple challenges both in new build and upgrading the existing stock. How these challenges are addressed will have long term impacts on building fabric, occupant comfort and wellbeing. Building performance simulation has an important role to play in this process, yet it is widely recognised that over-simplification in the modelling of physical phenomena leads to substantial sources of error. Moisture is a major cause of damage in buildings, and the Glaser method is a widely used steady-state method used to calculate the vapour pressure difference in a building's envelope. Although known for its limitations, it is the principal method used to assess moisture response in the UK. This paper evaluates the current situation in the UK, addressing fuel poverty targets, energy saving regulations and changing boundary conditions and their compounding implications for building envelope performance.
\end{abstract}

\section{Introduction}

Buildings play a major role in terms of the global energy consumption and Green House Gas (GHG) emissions (Winters, 2011). Consequently many Annex 1 governments have decided to drastically reduce their national carbon emissions by significantly increasing the thermal performance of their building stock (WAG, 2004). Overarching national emission reduction targets and corresponding guidelines are described in the report of Royal Commission on Environmental Pollution on the urban environment (DEFRA, 2008). At present, commercial, residential and industrial buildings use nearly $40 \%$ of the energy in the UK producing almost half of the $\mathrm{CO}_{2}$ emissions at a national scale. Nearly $60 \%$ of this energy consumption is used for heating and cooling of the premises; the rest is consumed by electrical appliances, lighting and other uses (DTI, 2001; Winters, 2011). Despite a continued fall in the proportion of energy used for water heating and cooking since the 1970's, there has been a pronounced rise in the 
proportion used for lighting and appliances (DECC 2012); this coupled with an expanding housing stock (DCLG, 2007a) means that the overall situation is worsening. According to the UK Government Environmental Audit Committee: “unless significant measures are put in place to reduce emissions from the housing sector ,from their current level of around $40 \mathrm{MtC}$ a year, they could constitute over $55 \%$ of the UK's target for carbon emissions in 2050; nearly doubling the current 30\% contribution.” (House of Commons, 2005, p48 item 125).

In tandem with meeting its legally binding Green House Gas (GHG) emission reduction commitment (UK Parliament, 2008), the UK is facing many new challenges both in new build and upgrading of the existing stock, which will have long term impacts on building fabric and occupant comfort and wellbeing. Interventions in the existing stock such as the retrospective filling of cavity walls and the application of internal insulation in heritage buildings, or new requirements needed to meet advanced performance standards such as EnerPHit (Feist et al, 2012a) could significantly change the way these buildings perform. In new build, advanced performance standards such as Passivhaus (Feist, 2012b) and the Code for Sustainable Homes (CfSH) (DCLG, 2010) Level 4+ often result in a win-win situation where energy savings also result in improved fabric quality and occupant comfort, but this is not always the case. In terms of hygrothermal risk analysis the Glaser method, whilst known for its limitations, is still the main method used in the UK to evaluate the overall moisture response.

This paper sets out to evaluate some of the key issues inherent in current UK policy and praxis, in more detail. These issues are explored by examining the challenges imposed by the upgrading of the existing building stock whilst addressing fuel poverty targets, energy saving regulations and changing hygrothermal boundary conditions. 


\section{UK Building Regulations and current practice in hygrothermal assessment}

\subsection{Current practice}

The 1985 Building Regulations were the first to include the UK's modern system of Building Control. Under the 1984 Building Act provision was made for future changes to technical specifications using a system of Approved Documents (England \& Wales) and Technical Standards (Scotland and Northern Ireland) (Killip,2005).

Despite the adoption of Part L of the UK Building Regulations, which were designed to conserve fuel and power, there is currently only limited legislative scope for their application in partial refurbishment work (HM Government, 2010a). Alongside this, demolition and replacement rates in the UK housing stock are extremely low with figures suggesting that the existing housing stock is currently being replaced once every 1300 years (Boardman, 2007). This means that only a very small percentage of the UK building stock would comply with modern building regulations.

Even when new dwellings are built a number of reports suggest that there is often a large discrepancy between the design performance mandated by Part L of the Building Regulations and what is actually constructed. In an unpublished 2005 Sustainable Energy Authority of Ireland report (BBC, 2008) it was not only found that many new build homes failed to meet energy and building regulations; it also pointed out that "92 per cent of the houses failed to meet minimum insulation levels", whilst "42 per cent did not (even) meet minimum ventilation standards” (BBC, 2008) which are considered necessary to reduce surface condensation risks, dampness and associated problems to human health. A similar National Home Energy Rating report (NHER, 2005) showed that out of a sample of 200 new build dwellings, tested post completion, over 1/3 would not have met the Part L requirements. Studies demonstrating a marked difference between what building energy models predict and the reality of what is built are not uncommon (Norford, 1994; Doran, 2000; Oliver, 2001; Bordass et al, 2004; EST, 2004; Sanders \& Phillipson, 2006). 
In response to these findings the UK Governments Environmental Audit Committee (EAC) stated that they "are alarmed at the apparent ease and possible extent of non-compliance with part L of the Building Regulations" (House of Commons, 2005, p45 item 116). The EAC found that "The fact that compliance with Part L of the Building Regulations is not covered by new buildings insurance, combined with a lack of post-completion inspections by Building Control bodies, provides little incentive for developers to carry out work to a standard that ensures proper compliance with energy efficiency requirements” (House of Commons, 2005, p45, item 117).

The recently revised Building regulation Part L1A for new build dwellings (2010) provides current guidance on the conservation of fuel and power in UK homes, and aims to reduce $\mathrm{CO}_{2}$ emissions by $25 \%$ over Part L1A 2006. Part L1A (HM Government, 2010b) is largely based on demonstrating that whole building carbon emissions comply with the method set out in the UK Standard Assessment Procedure (SAP) 2009. Approved document LIA (2010) also provides limiting (worst case) fabric U-value for external walls to $\leq 0.3 \mathrm{~W} /\left(\mathrm{m}^{2} \cdot \mathrm{K}\right)$ and $\leq 2.0 \mathrm{~W} /\left(\mathrm{m}^{2} \cdot \mathrm{K}\right)$ for windows ((HM Government, 2010b, p15). This is whilst Part F (2010) regulations address air tightness and ventilations issues. In order to harmonise these two standards recent revisions have been made to control the background air leakage from UK dwellings. Currently Part L1 (2010) specifies that air leakage should not exceed 10m3/m2.h at 50Pa. (HM Government, 2010b, p15). This level of airtightness is equivalent to allowing a hole the size of a twenty pence coin in each square meter of the building envelope (BRE, 2012). New legislation was also implemented in Part F (2010) to ensure that more airtight dwellings ( $<5 \mathrm{~m} 3 / \mathrm{m} 2 . h$ @ 50Pa) had adequate trickle ventilators or mechanical ventilation due to concerns regarding reduced Indoor Air Quality (IAQ) standards in airtight dwellings. Part L and Part F regulations are revised approximately every 3 years with the intention that by 2016 all UK new build dwellings should become 'zero carbon' by definition.

\subsection{Part $L$ and implications of the revised 'zero carbon' definition}

Achieving $\mathrm{CO}_{2}$ emission cuts of $80 \%$ from the total UK housing stock by 2050 (UK Parliament, 2008) represents an enormous technological and logistical challenge (Boardman, 2007). Historically low stock 
replacement rates in the UK means that the majority of newly built dwellings will create additional stock that simply adds to the emissions problem (McLeod et al, 2012a). By 2050 it is estimated that there could be as many as $23 \%$ to $40 \%$ (DECC, 2010) more households in the UK with the anticipated construction of approximately 240,000 homes each year (DCLG, 2007a).

With respect to new build housing, the British government intend to incrementally increase the $\mathrm{CO}_{2}$ emission reduction requirements implemented via the Building Regulations every three years between 2010 and 2016. The key points of these new standards are:

- Achieve a reduction of $25 \%$ in new build carbon emission in 2010 over the previous standard (2006) (CSH Energy Level 3)

- Followed by proposals for a 44\% reduction in 2013 (CSH Energy Level 4)

- In 2016, all new homes will be defined as ‘zero carbon’ (CSH Energy Level 6).

The original definition of ‘true zero carbon’ stated that: “Net carbon dioxide emissions from all energy used in the dwelling are zero or better”. In addition, “a zero carbon home is also required to have a Heat Loss Parameter (covering walls, windows, air tightness and other building design issues) of $0.8 \mathrm{~W} / \mathrm{m}^{2} \mathrm{~K}$ or less, as well as net zero carbon dioxide emissions from use of appliances in the homes (i.e. on average over a year)” (DCLG, 2007, p29).

The revised 'zero carbon' definition however addresses only the portion of operational emissions that are accounted for in the UK Standard Assessment Procedure (SAP) (ZCH, 2009a; HM Treasury 2011). SAP (2009) accounts for the energy consumed by the main and secondary space heating systems, space cooling, domestic hot water, building services pumps and fans and fixed lighting, but not energy used for cooking or domestic appliance consumption (DECC, 2011)

The previous Part L (2006) methodology is estimated to have omitted between one third (Reason and Olivier, 2006) and a half (DCLG, 2007a) of the total $\mathrm{CO}_{2}$ emissions from a UK dwelling. Given that domestic appliance consumption is rising (DECC, 2012) and that heating demand is falling as a result of 
climate change (McLeod et al , 2012b) it is likely that the revised definition of 'zero carbon' will affect substantially less than half of the total operational emissions from new build dwellings (McLeod et al, 2012a).

Where the new policy differs significantly from the previous definition is in the inclusion of a third tier based on the use of cost capped 'allowable solutions'. The concept of 'allowable solutions' was promoted by the ZCH since "rather than placing reliance solely on the development itself (through energy efficiency and on-site renewable energy) to deliver zero carbon, a range of additional, mostly off-site solutions, would be made available to developers in the new definition" (ZCH, 2009a). For further explanation and a detailed analysis of the concept of 'allowable solutions', please see McLeod et al. (2012a).

In terms of the net climate change impacts from new buildings it is not only the operational energy use that is registered in the atmosphere however. According to McLeod (2007) and Eurobuild (2012) the embodied carbon emissions in a conventional masonry Passivhaus dwelling may account for between 30 and $50 \%$ of the total 60 year GHG emissions (depending on the type of heating system used). Given the significance of these unregulated emissions and the fact that the vast majority of new dwellings create additional stock, any carbon emission savings achieved under the revised definition of 'zero carbon homes' are unlikely to make a positive contribution to the $80 \%$ emission reduction target, mandated for 2050, under the UK Climate Change Act (UK Parliament, 2008). When the net GHG emissions (including embodied energy) are considered in the context of a low energy dwelling the on-site savings achieved by the revised zero carbon definition diminishes to as little as one sixth of the total GHG emissions incurred over a sixty year period (Figure 1).

\section{Figure 1}

Given the magnitude of the existing stock, coupled with historically low replacement rates (Boardman, 2007) and generally poor standard of energy efficiency amongst the existing UK housing stock (DCLG, 
2007c) (Olivier, 2001) suggests that a re-emphasis towards standards to upgrade the existing stock are likely to achieve far greater net energy and carbon savings.

In terms of legislation affecting the thermal upgrading of existing buildings, Part L1B applies to the removal and reinstatement of existing dwellings as well as upgrading the existing envelope (BR L1B, 2010). A large number of buildings in the UK are exempt from Part L1B legislation however, due to their conservation status (BR L1B, 2010). In England alone there are approximately 374,081 listed building entries (English Heritage, 2012). Although listing is not a preservation order, Listed Building Consent is required to make changes to the fabric of a listed building and this includes common replacement works such as changing windows and doors as well as any work affecting the building fabric (English Heritage, 2012). In buildings with Grade I or Grade II* status substantial thermal upgrading may not be permissible.

According to L1B the individual element limiting U-value for walls should not exceed $0.7 \mathrm{~W} /\left(\mathrm{m}^{2} \cdot \mathrm{K}\right)$. Although such backstop (or worst case) U values are stipified in Part L, they are rarely enforced. Part L compliance is typically evidenced via a 'whole building' carbon emission methodology based upon the outputs from a SAP calculation. As such, the predicted $\mathrm{CO}_{2}$ emissions reductions -relative to a 'notional' building of the same format with a fabric specification designed to meet the previous Part L standards and with boundary assumptions derived from the National Compliance Methodology (NCM) - has become the defining standard. If the 25\% reduction is made then the Dwellings Emission Rate (DER) will be less than the Target Emission rate (TER) and the dwelling is deemed to comply with Part L. In reality, no thermal upgrade may be needed to achieve compliance in this manner since simply switching from a conventional gas heating system to an equivalent biomass pellet heating system would effectively reduce the $\mathrm{CO}_{2}$ emission intensity by a factor of 7 (SAP, 2009, p199), thus far exceeding a notional 25\% improvement in the DER. Therefore contingent upon the fuel type, building format, heating system or installed Low and Zero Carbon Technologies (LZCTs) used to reduce the SAP regulated carbon 
emissions anything from a nearly Passivhaus standard envelope down to something that could have been the default elemental standard 10 years ago may still be permissible for Part L compliance.

In contrast to the emission reductions achieved via small LZC technologies and energy efficient appliances, many of which are unlikely to last beyond 10 -20 years (Phillips et al, 2007; Seiders et al, 2007), fabric measures implemented via quality assured design approaches such as the Passivhaus standard are likely to achieve carbon savings that will exceed 60 to 100 years (BLP, 2007). Likewise changing the carbon intensity of the fuel source does nothing to alleviate fuel poverty or improve Indoor Air Quality (IAQ) issues. Addressing all of these contiguous issues will only occur by focusing on the reduction of unwanted thermal losses and gains through the envelope of buildings as well as uncontrolled air infiltration losses. One of the most straightforward solutions is to use appropriate insulation in order to substantially improve the operational energy efficiency of a building, thereby directly reducing their long term energy consumption and to global $\mathrm{CO}_{2}$ emissions.

In terms of the building fabric, under the revised definition of 'zero carbon', the Fabric Energy Efficiency Standard (FEES) would provide a national minimum energy efficiency specification for zero carbon homes (ZCH. 2009b). This performance specification has significant implications since it effectively defines a national minimum insulation and airtightness standard as well as having implications for the climate change adaptation and the mitigation potential of the UK's future housing stock (McLeod et al., 2012a). The proposed FEES standards mandates limiting the specific heat demand (SHD) of detached, semi-detached and end terrace ‘zero carbon' dwellings to $46 \mathrm{kWh} / \mathrm{m} 2$.yr and for apartments and midterraced dwellings to $39 \mathrm{kWh} / \mathrm{m} 2 . y r$ (ZCH. 2009) based on the SAP(2009) methodology. Modelling carried out by the ZCH suggests that, in order to comply with the FEES standards, fabric standards will have to meet or exceed those set out in Table 1.

\section{Table 1}


It should be noted that the SAP calculation takes account of thermal bridging, at junctions between elements and around openings. If linear thermal transmittance $(\Psi)$ values are available for these junctions, they can be multiplied by the length of the junction concerned, and the total added to the one dimensional transmission heat transfer coefficient.

$$
U=U_{0}+\frac{\sum_{i=1}^{n}(\psi L)_{i}}{A}
$$

Where $\mathrm{U}$ is the resultant $\mathrm{U}$ value after the two dimensional linear thermal bridging transfer coefficients are added. The three dimensional point bridging effects of fastenings and wall ties are normally included as adjustment factors in the $\mathrm{U}_{0}$ calculation in accordance with (EN6946, 2007). If specific values for linear thermal bridges are not known, an approximation is permissible by including a notional ' $y$-value’ allowance of $0.15 \mathrm{~W} / \mathrm{m}^{2} \mathrm{~K}$ based on the total exposed surface area (SAP, 2009).

It should be noted that the use of a ' $y$ ' value in accordance with the UK SAP (2009) convention involves a notional adjustment to the elemental $U$ value in order to incorporate the area weighted influence of linear thermal bridges $(\Psi)$.

A $y$-value is therefore the sum of $(\mathrm{L} \times \Psi)$ for all junctions divided by the total area of external elements, which includes exposed elements but not party walls, (DECC, 2011, p78).

$$
y=\frac{\sum_{i=1}^{n}(\psi L)_{i}}{A_{\text {exp }}}
$$

where $A_{\exp }$ is the total area of external elements

The assumption in the FEES standard is that the non-repeating thermal bridging can contribute to worsening the overall elemental $U$ values by $0.04 \mathrm{~W} / \mathrm{m}^{2} \mathrm{~K}$ for a detached house and $0.05 \mathrm{~W} / \mathrm{m}^{2} \mathrm{~K}$ for all 
other dwelling types (ZCH, 2009b). As such the y values permissible under the FEES standard allow for a worsening of the backstop elemental thermal transfer coefficients $\left(\mathrm{U}_{0}\right)$ by approximately $25 \%$.

Whilst the FEES standards are likely to be mandated as defining the minimum fabric standard for a 2016 'zero carbon' dwelling, it is notable that they fall significantly short of those proposed by well-established low energy standards including the German Passivhaus standard (Feist, 2012) the Canadian R2000 standard (NRCAN, 2012) or the Swiss Minergie P standard (Minergie, 2012) . There is however nothing to prevent developers achieving 'zero carbon' compliance through the voluntary use of these more advanced specifications, and indeed an increasing number of UK social housing developers are exploring the adoption of such standards as a means of improving energy efficiency whilst alleviating fuel poverty.

\subsection{Passivhaus (new build) and EnerPHit (refurbishment)}

Passivhaus is currently the fastest growing energy performance standard in the world with approximately 40,000 buildings realised to date (PHI, 2012; BRE 2012). It is an ultra low energy standard which necessitates the use of mechanical ventilation with heat recovery due to very high level of air tightness (Feist, 2012a; Feist, 2012b). A map of certified UK PH Projects can be viewed on the PH Trust webpage (PHI, 2012). The first certified Passivhaus projects in the UK were completed in 2009 and as a result it is still too early to assess whether significant hygrothermal issues will arise as a result of the construction methods used to achieve this advanced thermal standard. In the majority of cases it seems likely that the use of external insulation and internal vapour barrier layers are likely to reduce the risk of interstitial condensate forming within the structural elements of the building. However, several of the projects completed in the UK to date have adapted more conventional construction methods including the use of cavity wall constructions and lime based pointing and renders.

The risk of cracking of parge coatings to masonry block work and the tearing of membranes in timber frame construction is always possible and carries an associated risk of introducing approximately 360g of 
water vapour through a $1 \mathrm{~m}$ crack length (x 1mm wide) per day (BRE, 2012). Similar studies by the Institute of Building Physics, Stuttgart, have shown that under standard occupancy conditions as much as $800 \mathrm{~g}$ of moisture can be convected through a $1 \mathrm{~m}$ x $1 \mathrm{~mm}$ crack per day when exposed to a pressure differential of 20Pa (IBP, 1989) . Where vapour diffusion to the outside is possible the risks associated with localised construction defects may be reduced. However, such risks need to be carefully evaluated in their specific context particularly in constructions where synthetic renders, render boards, and other rain screen materials are applied externally without a vented cavity.

According to Quirotte (2004) constant cavity cycling poses a risk in well-sealed cavities due to the pressure fluctuations inside the cavity driven by variations in external air pressure. This cyclic phenomena occurs when the external air temperature drops (at night) drawing warm moist air in to the cavity from the inside of the building, where it is likely to condense. During the day in the presence of substantially warmer sol-air temperatures the air pressure flux within the cavity may be reversed, thus creating a 24 hour cycle. This phenomenon poses a potential future risk in the UK where sealed unvented cavities are increasingly specified in an attempt to improve the thermal performance of cavity walled buildings.

Figure 2 shows an example of a 'partially filled' timber frame and brick veneer cavity wall construction that is unvented (Cae Gleishon passivhaus).

\section{Figure 2}

According to the ideal gas law, the relationship between pressure, volume and temperature can be described by the following equation

And

$$
\begin{gathered}
P V=n R T \\
P_{1} V_{1} / T_{1}=P_{2} V_{2} / T_{2}
\end{gathered}
$$

Where $P_{1}$ and $P_{2}$ are absolute air pressure before and after temperature change (Pa)

And $T_{1}$ and $T_{2}$ are the initial and resultant air temperature during a cycle (K)

$V_{1}$ is the free air volume of the cavity $\left(\mathrm{m}^{3}\right), \Delta V$ is the displaced air volume $\left(\mathrm{m}^{3}\right)$

Since the cavity volume is constant $\quad V_{2}=V_{1}+\Delta V$ 
Hence, the volume of displaced air is $\quad \Delta V=\left(P_{1} V_{1} T_{2} / T_{1} P_{2}\right)-V_{1}$

Thus, for a given change in sol-air temperature or barometric pressure the displaced air volume of the cavity can be calculated. According to Quirouette (2004) this phenomena is widely documented during winter months in Northern Latitudes. In practice the severity of this phenomenon is proportional to the extent of the temperature change and the duration of each cycle, and will only occur when the outer leaf of the cavity is well sealed.

Where more traditional constructions such as cavity walls have been constructed in a fully filled manner such as in the Denby Dale Passivhaus (Figure 3) (GBS, 2010) or BedZED (Lazarus, 2002) further investigations may also be warranted. Of possibly greater significance than the diffusion and convection driven interstitial condensation risks outlined above; are potential problems associated with driving rain entering an unventilated cavity, particularly one which is not properly drained. The influence of driving rain on unvented cavity constructions where the outer layer is constructed from a porous stone material or brick (which may also be prone to cracking at the joints) has not been extensively researched in the UK.

Figure 3 shows a cross section of the Denby Dale Passivhaus wall construction, an example of a fully filled undrained Passivhaus cavity wall which is faced in porous sandstone with a lime based pointing. Although water repellent mineral fibre has been used as a precaution in this construction (Butcher 2012), there is no egress for trapped water or condensate. As a result moisture accumulation in the cavity could lead to saturation of the lower course of facing stone over time.

\section{Figure 3}


Ice expansion damage can result in structural cracking when rainwater seepage freezes in poorly drained cavities (Figure 3). The risk of this problem is elevated in super insulated and thermally Passivhaus wall constructions as a consequence of the high temperature gradients across the construction.

Figure 4

Sol-air temperatures below freezing (at night) on the outside of super insulated buildings following spells of driving rain are likely to lead to spalling and frost damage where trapped moisture freezes within the outer layer of porous or sorbtive materials (Figure 5). Modern bricks are predominantly frost resistant however it is important to consider this issue before post filling existing cavity walls. Super- insulated timber frame constructions are also vulnerable to this phenomenon. Transient hygrothermal analysis accounting for the directional dependence of localised driving rain is recommended before the use of hygroscopic cladding materials, such as lime based renders, are specified as a surface coating to sorbtive materials such as woodfibre board (as for instance in the Lime Passivhaus at Ebbw Vale).

\section{Figure 5}

Further, even air alters moisture flow at the micro-scale (Descamps, 1997). Once a material is wet, the capillary sucked water displaces air out of the material's pores until only enclosed air bubbles are left (Hens, 2012). This phenomenon is known as the capillary moisture content and basically states that the value of the moisture uptake is sometimes limited to a value well below saturation.

None of these relationships are linear and as the air temperature increases, the Saturated Vapour Pressure (SVP) also increases exponentially (Tetens, 1930; Murray, 1967). This relationship has implications for the phenomena of reverse diffusion or summer condensation, where the moisture flux is reversed. 
Buxbaum et al $(2007 ; 2008)$ have demonstrated that there is a risk of moisture vapour entering the vapour permeable outside layers of some Passivhaus constructions and condensing on the external face of the internal Vapour Barrier. For this reason Buxbaum (2007) recommends that internal vapour retarders with high SD values should not be used in timber construction, and that vapour permeable materials such as OSB-3 or intelligent membranes offer a better solution. The high external temperatures needed to drive a strong reverse vapour pressure differential are relatively rare in the UK, however inward diffusion of moisture vapour may readily occur as a result short wave radiation absorption warming external surfaces saturated by driving rain (Kuenzel and Zirkelbach, 2011; Quirouette, 2004) . UK climate change projections indicate that increasingly warmer and wetter summers are likely for much of the UK (Jenkins et al, 2007) this suggest that pre-cautionary assessment of this risk is advised, particularly where the structural elements of timber frame or steel constructions may be at risk.

The EnerPHit standard was launched by the Passive House Institute, in 2010 as a trial standard for use in retrofitting existing properties that would otherwise be too difficult or costly to refurbish to the full Passivhaus standard (PHI, 2010). Where insulation can be applied externally in a continuous manner the EnerPHit standard is unlikely to present challenges from a hygrothermal perspective (except where water is trapped in the construction during installation).

The EnerPHit standard specifies that the overall thermal transmission coefficient of internally insulated walls must be $<0.35 \mathrm{~W} / \mathrm{m}^{2} \mathrm{~K}$ (PHI, 2012a). Whilst in the case of internally insulated floors the thermal transfer coefficient multiplied by the ground temperature reduction factor $\left(\mathrm{f}_{\mathrm{t}}\right)$ should be $<0.15 \mathrm{~W} / \mathrm{m}^{2} \mathrm{~K}$ (PHI, 2010). The guidance documents also state that interior surface temperatures of the ground floor covering must result in an internal floor surface temperature of at least $17^{\circ} \mathrm{C}$ for the design conditions (assuming an indoor set point temperature of $20^{\circ} \mathrm{C}$ ) (PHI, 2010). Assuming a typical annual ground temperature reduction factor range in the UK of 0.62 (Central London) to 0.75 (Outer Hebrides) (Feist, 
2012) then this would imply that the actual U values for the floor build up should be no greater than 0.2 $0.24 \mathrm{~W} / \mathrm{m}^{2} \mathrm{~K}$, depending on the location. This would be equivalent to adding approximately $14 \mathrm{~cm}$ (or more) of XPS insulation (lambda value $0.035 \mathrm{~W} / \mathrm{mK}$ ) to the warm side of an un-insulated concrete slab.

Such targets are necessary if radiant surface temperature asymmetry is to be minimised within the limits of acceptability set out in EN ISO 7730 whilst achieving an overall specific heating demand of $\mathrm{Q}_{\mathrm{H}} \leq$ 25kWh/m².yr (Feist, 2012a). Implementation of the EnerPHit standard can presents significant technical challenges where ambitious energy reduction targets are imposed in contexts where thermal bridging issues and interstitial condensation problems are likely to be exacerbated. When internal insulation is applied the temperature gradient across the wall/ floor or roof element will become more pronounced and existing structural elements will be at much lower temperatures in winter. This will reduce the drying potential of saturated walls and could also lead to significant frost damage where temperatures fall below freezing point.

Thermal bridges are likely to be exacerbated where internal insulation is used, particularly at junctions where the insulation is not continuous. Careful detailing around all junctions (including window reveals, party walls etc.) is needed to ensure that internal surface temperatures do not fall below a minimum threshold of $12.5^{\circ} \mathrm{C}$ (Pfluger, 2006). This guidance is based on the assumption that with an internal air temperature of $20^{\circ} \mathrm{C}$ the dewpoint temperature will occur at $12^{\circ} \mathrm{C}$ (with an internal $\mathrm{RH}$ of $60 \%$ ). In such situations two and three dimensional analysis of thermal bridges and transient hygrothermal modelling will almost certainly be required to determine whether long term damage is likely to occur either via mould growth or moisture accumulation.

Thermal bypass, possess another serious risk where internal insulation is used. Warm air convected around or through internal insulation due to a breach in the airtight barrier (or an internal cavity) can lead to air with a high vapour pressure condensing on cold surfaces deep within the construction. Problem areas include window frame junctions and the ends of timber joists in floors and ceilings. Internal 
insulation must therefore be installed in an airtight manner; Pfluger (2006) suggests that a target $\mathrm{q}_{50}$ value below $0.6 \mathrm{~m}^{3} / \mathrm{m}^{2}$.h should be maintained for this reason. A detailed study of the long term performance of 14 different internal insulation approaches (including capillary active insulation materials) used in conjunction with different types of vapour retarders across a range of driving rains zones can be found in AkkP 32 (2005).

The EnerPHit guidance was amended in 2012 to define a new standard 'EnerPHit ${ }^{+\mathrm{i}}$ ' which applies to situations where more than $25 \%$ of the opaque external wall area is to be internally insulated (Feist et al, 2012a). Although internal insulation is often the only acceptable route to refurbishing dwellings in the UK that are subject to conservation or planning restrictions, the risks inherent in this process cannot be neglected. In practical terms a comprehensive survey of the existing building fabric and services should be carried out before internal insulation is specified. Potential risks such as: inhomogeneous materials and voids, heating pipes embedded in the outer wall, air leakage paths at critical junctions, thermal bridges and convective bypass routes must be carefully assessed before internal insulation is installed. Altering the hygrothermal behaviour of an outer wall which is acting as a rain screen or buffering system could have significant consequences for the long term durability of the building fabric.

The revised EnerPHit guidance states that: for interior insulation proof of suitability must be provided by means of an expert report based on accepted testing procedures (e.g. hygrothermal simulation) (PHI, 2012a). This is the first time that an energy performance standard adopted in the UK has mandated third party indemnity procedures with respect to hygrothermal risk assessment.

\subsection{UK legislative guidance Part C and EN 13788}

Although rarely referred to, the UK Building Regulations Approved Document C (ADC) (BR ADC, 2010) addresses site contamination (Part C1) and moisture for new build construction (Part C2). Amongst other information ADC2 provides additional information for different wall constructions, 
insulation types and finishes or cladding to be specified appropriate to the regional driving rain location in the UK (see Figure 6).

\section{Figure 6}

For example, it is stated that in the regions prone to severe driving rain (zone 4) either an impervious rain screen or complete rendering of the facing masonry is advised (BR ADC, 2004, p35). Such guidance stands in significant contrast to what has actually been implemented in much of the recent UK building stock where brick walls often with recessed pointing are found in regions with 'severe'(zone 3) and 'very severe'(zone 4) driving rain exposure (Figure 6).

However, although Part C is an Approved Document and part of the UK building regulations, this section is considered to be 'guidance' rather than an enforceable requirement.

Moisture content has an important impact on the building performance. These effects range from modification of the thermal performance of insulation, through to structural collapse of buildings and chronic health issues. Moreover according to (Hens, 1990) there are serious risks of surface mould formation if the inside of the building envelope reaches equilibrium at $80 \% \mathrm{RH}$ (relative humidity). Not only is building performance affected by moisture but indoor air quality (IAQ) and hygienic conditions become less favourable as moisture levels rise above an optimum threshold. Mould and dust-mites allergens are closely correlated to indoor Relative Humidity (RH) levels above 45\%RH (Emenius et al. 2004; Franchimon, 2009) and are directly attributed as a causal agent of allergies and asthma (Pulimood et al., 2007). The UK has one of the highest rates of asthma in the world (Covey, 2004) and its regional prevalence is closely correlated to areas of high rainfall and fuel poverty (Asthma UK, 2008).

\section{Hygrothermal consequences of high insulation values}

\subsection{The Glaser method (in practice) and its application and limitations}


The Glaser method (BS EN ISO 13788-2002) analyses the moisture balance of a building component by considering vapour diffusion transport from its interior. Developed during the late 1950’s the Glaser method was originally intended as a means to evaluate interstitial condensation on freezer walls (Glaser, 1959). Nevertheless, it became one of the most common tools used to analyse the moisture balance of building components, and is commonly referred to as the "dew-point method" in the USA (ASHRAE, 1993). It was subsequently upgraded by including capillary action and by the incorporation of more realistic indoor and outdoor boundary conditions (Hens, 2012).

Although it has become a commonly adopted method, it cannot always be relied upon to give a reliable indication of vapour diffusion and moisture behaviour through the building structure due to its simplified steady state assumptions. In reality, dynamic simulation tools that are capable of accounting for thermal and hygric inertia (sorption/desorption), for capillary moisture movement, as well as taking into account variations in non-homogenous material property values, whilst allowing consideration of wind-driven rain, building moisture sources etc. are more likely to produce reliable predictions. None-the-less, Glaser is still the most commonly used method in the UK and is widely used to determine surface and interstitial condensation phenomenon and the ancillary risk of mould growth and is incorporated in several widely used in building energy models and U-value calculators (including BuildDesk Energy, IES-ve, Hevacomp, JPA Designer, amongst others). As far as realistic transient heat and moisture simulation is concerned, it provides a general method to assess the suitability of a building component. This method states that it is possible to calculate the vapour pressure evolution in a building in a similar manner to which one determines the temperature evolution through the building component.

According to the Glaser method, condensation will appear on or within a layer where the calculated vapour pressure exceeds the saturation vapour pressure at a given temperature (i.e. the dew point temperature is reached). Generally, the overall moisture response is more pronounced in winter, as the vapour pressure gradient across a construction element is higher at this time due to lower external temperatures which limits the absolute moisture content (and hence saturation vapour pressure) of the 
external air. Since interstitial condensate typically accumulates at the interface between construction materials or within a porous material layer one often only discovers the consequences of this on the internal surface of the building after several years. In some circumstances, such as inside cellulose based insulation materials or structural timbers, the condensate may have caused irreversible damage at this point. Theoretically, the amount of interstitial condensate forming in winter and the amount of evaporable water in summer can be evaluated using the Glaser method as well. If the materials are able to seasonally absorb and desorb the amount of moisture without creating long term build up (Künzel, 2000) there is, in theory, no problem. The Glaser method assumes that a given amount of built-in water will dry out during the summer period based on the boundary conditions used, however this method does not take into account a number of important physical phenomena (including the transient nature of boundary conditions) and consequently the method is applicable only to structures where these effects are negligible. The application and limitations of the method have been described in BS EN ISO 13788-2002.

According to Künzel (2000) in one study comparing the interstitial condensation predictions in roof constructions, the Glaser method and the dynamic simulation software (WUFI) gave fairly similar results. However, Künzel points out that short time step variation in the boundary properties using the Glaser method are limited and that is why it is in some cases essential to use dynamic simulation tools. One example might be the effects of solar and long wave re-radiation on sol-air boundary temperatures or, perhaps more importantly in a UK context, the influence of driving rain or melting snow which may affect the moisture conditions but are neglected in steady-state calculations.

In the United Kingdom where large regions (such as Northern Ireland, and Western coasts of Wales, Scotland and the SW) are confronted with severe driving rain (see Figure 5), the use of dynamically coupled heat and moisture simulation becomes increasingly more important.

In a study conducted by May (2009), the difference of three different wall constructions, of approximately similar $U$ values, located in two different climate zones is shown. One is modelled under a moderate 
climate in London and the other one being located in Swansea/ Wales facing severe driving rain (cf. Figure 5).

May’s (2009) study shows the failure of conventional insulation materials such as using PU foam insulations by demonstrating the moisture content rising in the wall construction over time and reaching its critical failure point after only 2 years time in the relatively sheltered London location; even worse, the same construction is predicted to fail within the first 9 months if located in a more severe climate such Swansea.

In contrast to the Glaser method, dynamic hygrothermal simulation, incorporating transient heat and moisture transport in one/ two-dimensional assemblies, becomes possible. This approach includes the possibility of more realistic modelling of material properties. Some material properties are easy to measure (density, dry thermal conductivity, the sorption isotherm, vapour permeability and air permeability) (Hens, 2012), others however, for instance moisture diffusivity and thermal moisture conductivity demand complex and time-consuming tests (Roels, 2008; Hens, 2012).

\subsection{Modelling uncertainty in material data and outputs}

Hens (2012) points out that despite such advances limitations still exist in dynamic modelling due to "too simple material modelling and uncertainty in material properties”. Figure 7 shows the results of a series of dry cup vapour resistance factor measurements on 30 facing brick samples from the same production batch in order to demonstrate the problem of non homogeneity in building materials.

\section{Figure 7}

Natural variation in material data creates uncertainty in modelling parameters which cannot be resolved in a straight forward manner. Building materials are heterogeneous by nature. In a study by Woloszyn and Rode (2008) it was shown via several whole building design calculation methods that relying upon the assumption that heat and moisture transfer can be neglected produces significant uncertainty in the 
outcome. This uncertainty increases even more when air and moisture transfer is taken into the account. The results show variations of up to 370\%. Costola (2011) tries to minimize this modelling uncertainty by coupling building energy simulation with heat and moisture simulation and thereby reducing uncertainty in the modelling process.

Physical uncertainties are mostly identifiable as the standard input parameters in energy, thermal comfort or heat and moisture simulation. Physical uncertainties refer to physical properties of materials such as thickness, density, thermal conductivity, or hygrothermal properties etc., of wall, roof and floor layers. Due to the manufacturing processes and random variations occurring in natural materials such uncertainties are always present, and thus, inevitable (Hopfe, 2009; Hopfe and Hensen, 2011). Obtaining sufficient information about specific variations in material properties is not always straight forward - especially in the case of natural materials such as sheep wool, cork, hempcrete and strawbale. Information about the physical properties of such materials is often either very limited or differs significantly according to different sources and measurement techniques (e.g. Adensam et al., 2005; Christian et al., 1998; Hens, 2012). The introduction of new harmonised European product standards EN 13162 to EN 13171 (amongst others) is intended to establish a level European playing field for all commercially manufactured insulation materials. This has led to the adoption of what is known as the $\lambda 90 / 90$ assessment method for insulation materials, which adopts a bench mark based on the $90^{\text {th }}$ percentile confidence level being achieved by 90\% of production output (Figure 8) (BBA, 2012) What may be more helpful in assessing the uncertainty in hygrothermal analysis would be to have information regarding the range of key parameters within an appropriate confidence level.

\section{Figure 8}

Variations or uncertainty regarding material moisture content or specific hygrothermal properties as well as variations in the sources or heat and moisture within the building envelope will in reality significantly affect the thermal and hygric performance of the building. If for example an insulation material becomes wet, the thermal conductivity of the insulation material will increase, which consequently affects the 
buildings energy consumption. Taking these compounding uncertainties into account is ultimately related to quality assurance. Despite the designers best attempt at quality assurance there will always remain a degree of uncertainty that he/she has no influence on.

In the case of strawbale for example, Walker et al (2011) observed changes in density varying from 100$130(\mathrm{~kg} / \mathrm{m} 3)$ and in terms of thermal conductivity of 0.05-0.065 (W/mK). Organic materials such as straw, cork, etc. are strongly hygroscopic and therefore have non-linear vapour permeability characteristics. The influence of such transient material properties is likely to be underestimated in current data even that used in dynamic simulation, when considering the in-situ behaviour in high humidity regions such as the UK. Most material databases do not yet contain such data in relative humidity ranges and literature reviews often provide incomplete information. An example for different sources for bulk density, thermal conductivity and water vapour diffusion resistance for strawbale is shown in Table 3.

\section{Table 3}

\subsection{Weather data uncertainty}

The UK is a nation of varied micro-climatic contexts, and a diverse existing building stock. The adoption of dynamic hygrothermal simulation, if correctly implemented, can be seen as a step forward in both the diagnostic recognition of typological problem areas and the prevention of future damage to individual buildings.

Accurate in-situ prediction of moisture problems in buildings requires boundary data sets which reflect the internal and external conditions that the building is likely to face. The key parameters needed to model the climatic influences on a building include the following (IBP, 2010; Künzel, 2006.; Künzel and Zirkelbach, 2011):

- $\quad$ rain load vertically incident on the exterior surface in $\left[\mathrm{L} / \mathrm{m}^{2} \mathrm{~h}\right]$

- solar radiation vertically incident on the exterior surface in $\left[\mathrm{W} / \mathrm{m}^{2}\right]$

- $\quad$ temperature of the exterior air in $\left[{ }^{\circ} \mathrm{C}\right]$

- relative humidity of the exterior air [0 -1]

- temperature of the interior air in $\left[{ }^{\circ} \mathrm{C}\right]$

- relative humidity of the interior air $[0-1]$ 
- $\quad$ barometric pressure in $[\mathrm{hPa}]$.

- long-wave atmospheric counter-radiation $\left[\mathrm{W} / \mathrm{m}^{2}\right]$, if night time radiative cooling is to be accounted for

Rain load and radiation are directionally dependent quantities, however in conventional weather station measurements they are usually only recorded on horizontal surfaces. With knowledge of the vertical rain load and the wind velocity and direction it is possible to compute the directionally dependent driving rain. Likewise the amount of radiation incident upon any given surface tilt direction or slope angle can be determined from knowledge of the global and diffuse radiation components incident on a horizontal surface for a given latitude and time (Muneer, 2004). WUFI performs these directional conversions automatically and will recognize data files in .WAC or .WET or .TRY or .DAT or .IWC format. In some cases an additional file (.AGD) is needed to supply geographical data regarding the climate location (IBP, 2010). Although data is available for a wide number of locations worldwide using the ASHRAE IWEC data (.iwc) caution is advised as this does not typically contain quantitative rainfall data $(\mathrm{IBP}, 2010)$.

By integrating the dynamic hygrothermal capabilities of WUFI with the quasi steady state energy model PHPP the Fraunhofer Institute have produced WUFI-Passive (Fraunhofer IBP, 2012). This integrated design tool was originally developed for the U.S Passivhaus market where issues of cooling and dehumidification are more pronounced than in central Europe. The WUFI-Passive software avoids the double entry of common data from the building energy model to the hygrothermal model ensuring that valuable hygrothermal outputs are now available to designers at the early stages of design.

Currently the WUFI software does not contain any default climate data for the UK and this may be a factor in limiting its adoption by less experienced practitioners. None-the-less there are a number of options available to obtain suitable hygrothermal weather data for the UK. TRY data is readily available from the CIBSE for 14 UK locations. CIBSE is due to release future probabilistic weather files in the form of Test Reference Years (TRYs) and Design Summer Years (DSY) derived from UKCP09 scenarios that cover three time periods, three emissions scenarios, and three probability levels for each of the 14 locations available in the current CIBSE datasets. These future weather files were produced using the 
morphing method detailed in TM48: Use of climate change scenarios for building simulation (Shamash, 2012)

Several researchers have noted the limitations of using the "nearest neighbor method" of transposing climatic data from one micro regional context to another in building energy and moisture models (McLeod et al, 2012b) (Morehead, 2010) (Remund, 2010). In order to address this situation and provide a clearer statistical basis for decision making the PROMETHEUS project at Exeter University developed a new method for generating high resolution (5km grid data) in an EPW file format. Using primary outputs from the UKCP weather generator (Eames et al, 2010) created a series of probabilistic weather files in TRY and DSY format. The weather generator is a stochastic randomly seeded model which combines measured data from the UK Met Office with data downscaled from the Hadley Centre's Regional Climate Model (HadRM3) for various future climate scenarios (DEFRA, 2009). The method used by PROMETHEUS allows the development of current and future probabilistic datasets, following the IPCC SRES emission scenarios (IPCC, 2000), for use in building programs requiring hourly simulation time steps. A full description of the methodology including that used to derive missing variables such as future wind speed, wind direction and atmospheric pressure can be found in Eames et al (2010).

A further option for deriving data at sites where either measured or synthesized data is unavailable is through the use of the Meteonorm interpolation software. Meteonorm uses interpolation methods (such as 3D inverse distance models for global radiation) to create weather files in almost any output format for any location in the world (Remund, 2010). Although the use of interpolation has been shown to entail a level of inaccuracy (Rawlins, 1984) (particularly for Global Horizontal radiation and ambient temperature) Remund (2010, p32) points out that the root mean square errors (RMSE) for this method are typically less than when the "nearest neighbor" approach is adopted. Analysis carried out by the Fraunhofer IBP suggests that driving rain and wind data produced by Meteonorm can be too homogeneous in its distribution and therefore not always reflective of local conditions (IBP, 2010). In Germany the Holzkirchen climate dataset is commonly used in hygrothermal simulations as a 'worst case' 
reference location for driving rain. No such location has yet been adopted in the UK as a proxy for 'worst case’ analysis, however a number of locations situated within class 4 (ADC, 2004) 'very severe’ driving rain exposure categories would make suitable candidates. EN 15026 (2007) suggests a simplified proposal for the generation of extreme climate years by creating simple shift functions of $+2 \mathrm{~K}$ for a warm year and $-2 \mathrm{~K}$ for a cold year. Such approximations may suffice as part of an initial sensitivity analysis depending on the accuracy and temporal period being considered. Regardless of the climate data used a sound knowledge of the uncertainty inherent in the modeling process and familiarity with micro climate of the building being modeled are important pre-requisite for interpreting the outcomes of hygrothermal simulation.

Uncertainties in modelling and climate data are just a few of many other limitations in dynamic simulation. To date most commercially available models overlook air and wind intrusion as important factors when looking to the hygrothermal response of walls and roof constructions. Other limitations exist with respect to the modelling geometry of building components (the reality compared to what the tool allows), perfect hydraulic contact conditions, boundary conditions (for instance the randomness of wind driven rain) (Blocken, 2004). Further to this in order to provide comprehensive outputs there is a need to judge indoor air quality, health and durability (Hens, 2012) - challenges which are yet to be addressed by dynamic simulation models .

\section{Consequences of retro-fitted cavity wall insulation in response to carbon reduction targets and fuel poverty alleviation}

A number of UK government funded strategies have been implemented over the past decade in order to reduce fuel poverty and improve the thermal performance of Britain's worst performing housing. The 
current government carbon reduction scheme - Carbon Emissions Reduction Targets (CERT), is targeted towards electricity and gas suppliers to reduce the amount of carbon emissions from dwellings (Ofgem, 2011). The scheme was originally to be run from April 2008 to March 2011, but was extended to end in December 2012 (DECC, 2012).

Figure 9 shows different methods of saving carbon emissions under the CERT scheme, it can be seen that the most popular method was insulation, which included both loft insulation and cavity wall insulation (Ofgem, 2011).

\section{Figure 9}

By the end of the third year of the current scheme, 1,582,612 cavity walls had been insulated (Ofgem, 2011). This resulted in a saving of approximately $40.5 \mathrm{Mt}$ of carbon emissions (Ofgem, 2011). The most popular material used for the insulation of the cavity walls under this scheme was mineral wool (Ofgem, 2011).

During the first decade of the $20^{\text {th }}$ century there was a sharp rise in the use of cavity walls in UK dwellings as they were introduced to replace solid wall construction in order to reduce construction costs, and provide protection from rain penetration (English Heritage, 2010). It is estimated that $69 \%$ of dwellings in England have a cavity wall present; of which only $40 \%$ have cavity wall insulation (BRE, 2005).

\section{Table 2}

Comparing the percentage of dwellings with cavity wall insulation, across different regions of England, it can be seen from table 6, that the highest percentage of dwellings constructed with cavity wall insulation are located in the North East (BRE, 2005). 71\% of dwellings constructed in the South West have a cavity wall, of which 38\% have cavity wall insulation. This represents a slightly higher percentage 
of cavity wall insulation than the North East, where $36 \%$ of the dwellings have cavity wall insulation.

The cavity method of wall construction was first introduced in UK during the early Victorian period (English Heritage, 2010) and was widely adopted for dwellings during the 1920’s, (Energy Saving Trust, 2002) to reduce the effect of rain penetration on the internal envelope. This allowed rainwater and moisture to be removed from the building envelope through the cavity area of the wall (Osbourn, 1985). Many factors need to be considered before cavity wall insulation material can be retrospectively injected into a dwelling, such as rain penetration (Energy Saving Trust, 2002), location of the dwelling (Smith, 2005) and exposure (Which?, 2011) as well as the type of insulation to be injected (BR ADC, 2004). Inbuilt and Davis Langdon (2010) state that by installing cavity wall insulation in a dwelling, the risk of cold bridging, condensation and frost damage is increased.

Figure 4 shows that wind-driven rain affects various location of the United Kingdom differently. It can be seen that there is a significant difference from zones less than $56.51 / \mathrm{m}^{2}$ to zones that receive approximately 100 litres $/ \mathrm{m}^{2}$ of driving rain per spell in the UK. According to Edwards (2011) no consideration is given to wind driven rain or location of the dwellings during pre-assessment of the suitability of applying cavity wall insulation in a specific dwelling, despite guidance in Approved Document C (p35). Dwellings in various locations will all receive different amount of moisture penetrating into the cavity wall area. This observation is confirmed by Gellert (2010a; 2010b) who believes that location, latitude and altitude of a dwelling should all be taken into consideration, before the installation of cavity wall insulation is specified.

The Energy Saving Trust (2002) also recommends that the wall construction of dwellings should be taken into account before installing cavity wall insulation. Problems such as leaking gutters may cause the wall to be saturated, therefore potentially exacerbating problems after insulation has been injected into the cavity area. The British Standards Institute (BSI) BS 5618:1985 (1985) states that any defects that will 
subsequently affect the cavity wall after the injection of insulation, should be rectified before insulation is installed, and this should form a part of the contract.

\section{Conclusion}

It was aim of this paper to illustrate the current challenges facing the practice of hygrothermal assessment in the UK in the context of rapidly evolving building performance standards. The UK is characterised by highly localised climatic conditions and experiences extreme driving rain conditions along much of its Western border. The existing stock is characterised by a high percentage of historic buildings and historically low demolition rates (Boardman et al, 2005) ; this means that advanced thermal refurbishment measures will need to be applied to a very high percentage of the existing stock if the UK if it is to meet its climate change and fuel poverty abatement targets. Planning, space and aesthetic considerations suggest that a large percentage of the existing stock will need to be internally insulated in order to meet these targets (Boardman et al, 2005; Boardman, 2007; Killip, 2008).

The hygrothermal consequences of meeting ever higher standards of thermal performance have been widely overlooked in the race to reduce $\mathrm{CO}_{2}$ emissions, fulfil the energy efficiency commitments of utility companies and address fuel poverty targets. The UK Building Regulations currently provides disparate information on the Conservation of Fuel and Power (Part L) and the provision of Ventilation (Part F). This guidance needs to be harmonised with the inclusion of more robust guidance in Part C2, particularly with respect to advanced refurbishment measures and the use of porous and hygroscopic cladding materials in super-insulated wall constructions.

This paper highlights why there is clearly a need for more research to be conducted and demonstrates the evolutionary role that transient hygrothermal modelling can play in the refurbishment and design of the future UK building stock. Unless accompanied by widespread building physics training schemes, for UK building professionals, it seems likely that achieving deep refurbishment targets will engender serious 
risks for the moisture response and structural integrity of many UK buildings. Current de-facto practice of using steady state modelling (Glaser method) and homogenous material properties as a means of condensation analysis has been demonstrated to be unreliable, particularly in complex refurbishment cases. The widespread adoption of dynamic heat and moisture simulation should form part of the precautionary approach, particularly where significant levels of internal insulation are used and the dew point falls inside the thermal envelope. The development of new tools (such as WUFI-Passive) that couple heat and moisture processes in an integrated platform offer a potential solution by providing more reliable hygrothermal information early in the design process .

As with all building simulation tools the results obtained can only supplement and further assist a detailed knowledge of the existing structure, local weather patterns and careful on site implementation; factors that are indispensable to the effective realisation of modelled predictions in reality. Only by better understanding the 'real world' behaviour of the system being modelled and the limitations of the model itself can more robust predictions be achieved.

\section{Acknowledgements}

We would like to thank Bill Butcher (Director, Green Building Store) for providing construction details and images of the Denby Dale Passivhaus. We would also like to thank the Housing Futures Team of the BRE for their continued support with this research project. Further thanks are due to Schumacher College (in particular Jon Rae and Robert Somerville) and the Dartington Estate for access to their site. 


\section{Figure Captions}

Figure 1.Relative GHG emissions addressed by the revised UK zero carbon definition

Figure 2. Cross section showing the Cae Gleishon Passivhaus wall construction

Figure 3. Full fill 300mm cavity wall construction with sandstone cladding (image Green Building Store).

Figure 4. Ice expansion damage to the bottom of a poorly draining cavity wall, Ireland (source J.

Morehead)

Figure 5. Typical spalling damage on external brick facade caused by driving rain penetration

Figure 6. Impact driving rain in the UK (from http://www.innovateuk.org/_assets/pdf/climate\%20reportlib/designing4construction_bill_gething_climatechangereport-0510.pdf)

Figure 7. Dry cup vapour resistance value measured on 30 samples of bricks from a single production batch (Hens, 2012)

Figure 8. Showing the $\lambda 90 / 90$ assessment method (BBA, 2012)

Figure 9. Comparison of different method used in the Carbon Emissions Reduction Targets to reduce $\mathrm{CO}_{2}$ emissions up until August 2011 (Ofgem, 2011)

\section{Table Captions}

Table 1. Backstop fabric performance values required to meet the FEES standards (Adapted from ZCH, 2009a)

Table 2. Cavity wall insulation in dwellings dependent on location (Adapted from BRE, 2005) 
Table 3 Thermal conductivity and water vapour diffusion resistance for strawbale according to literature 


\section{References}

AkkP 32. 2005. Faktor 4 auch bei sensiblen Altbauten. Protokolband Nr. 32 des Arbeitskreises kostengunstige Passivhauser Phase III. Passive House Institut, Darmstadt 2005

ASHRAE, 1993, 1997, 2001, 2005, Handbook of Fundamentals, American Society of Heating, Refrigerating and Air Conditioning Engineers, Atlanta

ASHRAE. 2009. ANSI/ASHRAE Standard 160-2009: Criteria for Moisture-Control Design Analysis in Buildings. Atlanta: American Soc. of Heating, Refrigerating and Air-Conditioning Engineers, Inc.

Acton, R.U. 1994. (untitled report). Sandia National Laboratories(SNL). Albuquerque, New Mexico.

Adensam, H., Breinesberger, J., Staribacher M., Hiller, S., Unfried, G., Schwarzmüller, E., Hegedys, H., Frosch, V., Ganglberger, E., 2005, Fabrik der Zukunft als regionales Produktionsnetzwerk auf Basis nachwachsender Rohstoffe anhand eines Pilotprojektes im Bereich Dämmstoffe. Stroh kompakt, availble online http://www.nachhaltigwirtschaften.at/nw_pdf/0508_stroh_kompakt.pdf

Asthma UK, 2008. 'Wish you were here?’ report number PP0350508. Available asthma.org.uk

BBA (2012). Lambda 90/90, British Board of Agreement. No 40/10. Available at: www.bbacerts.co.uk/media/92047/040_4_lambda_90_90.pd

BBC news, ‘Record rise for British Gas bills’, Wednesday 30th July, 2008. Available at: http://news.bbc.co.uk/1/hi/business/7533389.stm

Blocken B., 2004, Wind-driven Rain on Buildings: Measurements, Numerical Modelling and Applications, PhD-Thesis, K.U.Leuven

BLP, 2007 online web portal for building life plan; available on http://www.blpinsurance.com/ (last accessed April 2012) 
Boardman, B., Darby, S. Killip, G. Hinnells, M. Jardine, C. Palmer, J \& Sinden, G., 2005. 40\% House Report. Environmental Change Institute. University of Oxford,

Boardman, B. 2007. Home Truths: a low carbon strategy to reduce UK Housing emissions by $80 \%$ by 2050. ECI Research Report 34, University of Oxford. ISBN 1874370435

Bordass, W., Cohen, R., and Field, J., 2004. Energy Performance of Non-Domestic Buildings: Closing the Credibility Gap. Proceedings of Building Performance Congress 2004 (IEECB'04) Frankfurt, Germany, 19-22 April 2004.

BRE 2005. Energy Use in Homes 2005. UK: Building Research Establishment.

BRE 2011. Passivhaus Available at http://www.passivhaus.org.uk/, last accessed 2011

BRE 2012. Passivhaus Airtightness Primer. Available at http://www.passivhaus.org.uk/podpage.jsp?id=72

BSI 1985. BS 5618:1985. Thermal insulation of cavity walls (with masonry or concrete inner and outer leaves) by filling with urea-formaldehyde foam system. London: British Standard Institution.

Building Regulation Approved Document L1A, 2010. Conservation of fuel and power for new dwellings, HM Government, Available on http://www.planningportal.gov.uk/uploads/br/BR_PDF_ADL1B_2010.pdf

Building regulation Approved Document L1B, 2010. Conservation of fuel and power for existing dwellings, HM Government, Available on http://www.planningportal.gov.uk/uploads/br/BR_PDF_ADL1B_2010.pdf

Building Regulations, Approved Document C, 2004 (incorporating 2010 revisions). Site preparation and resistance to contaminates and moisture, Date published: reprinted December 2010 
Butcher, B. 2012. Personal email correspondence in respect of the Denby Dale passivhaus construction $24^{\text {th }}$ July 2012

Buxbaum, C., Seiler, A., Pankratz, O. 2007. Analysis and comparison of the hygrothermal performance of passive house constructions in the Climate of Central Europe and Northern America. 10th International Conference on Thermal Performance of the Exterior Envelopes of Whole Buildings X, 02 - 07.12.2007, Clearwater Beach / Tampa, USA

Buxbaum, C., Schorer, M., Seiler, A., Pankratz, O. 2008. Study of the Moisture Performance of Highly insulated Building Envelopes. 12th International Passive House Conference Proceedings. 11-12 April 2008, Nuremburg.

Buxbaum, C. 2009. In conversation July 2009

Christian J, Desjarlais O, Stovall PE. 1998. Straw-bale wall hot box test results and analysis, ASHRAE Conference. The Thermal Performance of the Exterior Envelopes of Buildings VII-4b103, Florida, December 1998.

Costola, D. (2011). External coupling of building energy simulation and building element heat, air and moisture simulation. Eindhoven: Technische Universiteit Eindhoven. ((Co-)promot.: prof.dr.ir. J.L.M. Hensen \& prof.dr.ir. B.J.E. Blocken).

Covey, D., 2004. Where do we stand? Asthma in the UK today. PP0081204. Available asthma.org.uk Danielewicz, I., Fitz, C., Hofbauer, W., Klatecki, M., Krick, B., Krueger, N., Krus, M., Minke, G., Otto, F., Scharmer, D., Teuber, W., 2008. Grundlagen zur bauaufsichtlichen Anerkennung der Strohballenbauweise- Weiterentwicklung der lasttragenden Konstruktionsart und Optimierung der bauphysikalischen Performance. DBU, Az. 22430, Abschlussbericht, Holzkirchen, Kassel, Magdeburg, Oberursel, Sieben Linden, 24.September 2008; available online on http://www.dbu.de/OPAC/ab/DBUAbschlussbericht-AZ-22430.pdf 
IBP(Institute for building physics), 1989, Stuttgart Germany, Deutsche Bauzeitung (DBZ); Heft 12/89, pp1639

DECC, 2011. Standard Assessment Procedure SAP 2009 version 9.90 (March 2010).

DECC, 2012. Domestic energy consumption in the UK since 1970 Publication URN: 12D/291

Available at www.decc.gov.uk

DEFRA and DOE 2008. The Royal Commission on Environmental Pollution's report on the Urban Environment - Government Response April 2008. Available at: http://www.rcep.org.uk/reports/26urban/documents/government-response-rcep.pdf.

DEFRA. 2009. UK Climate Projections User Interface, 5km grid (available) http://ukclimateprojectionsui.defra.gov.uk/ui/docs/grids/wg_5km/index.php

Descamps F., 1997, Continuum and Discrete Modelling of Isothermal Water and Air Transport in Porous Media, PhD-Thesis, K.U.Leuven

DCLG, 2007a. Homes for the future: more affordable, more sustainable. Department for Communities and Local Government, London. Available at: www.communities.gov.uk/documents/housing/pdf/439986.pdf (Accessed January 4, 2011).

DCLG, 2007b.Code for Sustainable Homes Technical Guide. March 2007. Available at: http://www.communities.gov.uk/archived/publications/planningandbuilding/codeguideoctober2007

DCLG, 2007c. English House Condition Survey, 2005, Annual Report. Department for Communities and Local Government, London. Available at:

http://www.communities.gov.uk/publications/housing/englishhousesurveyannual 
DCLG, 2010. Code for Sustainable Homes: Technical guide - 2010. Department for Communities and Local Government, London. Available at:

http://www.communities.gov.uk/publications/planningandbuilding/codeguide

DECC. 2012. Carbon Emissions Reduction Target. Department of Energy and Climate Change. Available at: http://www.decc.gov.uk/en/content/cms/funding/funding_ops/cert/cert.aspx (Accessed 10 March 2012)

DTI 2001. Energy Consumption in the United Kingdom. London: Energy Publications, Department of Trade and Industry.

DIBt, 2006, Anstalt des öffentlichen Rechts. Deutsches Institut für Bautechnik. Available at: http://www.baubiologie.cz/slama/AbZ-Nr.-Z-23.11-1595.pdf

Doran, S., 2000. Field investigations of the thermal performance of construction elements as built BRE client report 78132 for DETR (report ref 36/8/79 cc 1637), November 2000 (revised June 2001), BRE, East Kilbride http://projects.bre.co.uk/uvalues/U-values.pdf

Eames, M., Kershaw, T., Coley, D., 2010. On the creation of future probabilistic design weather years from UKCP09. Building Services Engineering Research and Technology. October 20, 2010.

0143624410379934

Edwards, L., 2011. Can we rely on cavity wall insulation advice? (Online). Available at: http://conversation.which.co.uk/energy-home/cavity-wall-insulation-companies-can-we-rely-on-theiradvice/ (Accessed 21 February 2012).

Emenius, G., Svartengren, M., Korsgaard, J., Nordvall, L., Pershagen, G., and Wickman, M., (2004). Building characteristics, indoor air quality and recurrent wheezing in very young children (BAMSE). Indoor Air 14(1): 34-42. 
ISO 6946:2007. Building components and building elements - Thermal resistance and thermal transmittance - Calculation method. ISBN 9780580549373

EN ISO 15026. 2007 Hygrothermal performance of building components and building elements Assessment of moisture transfer by numerical simulation. Edition: 2007-06-01

Energy Saving Trust. 2002. Cavity Wall Insulation: Unlocking the potential in existing dwellings (Online) Available at http://www.haringey.gov.uk/cavity_wall_insulation.pdf (Accessed 21 February 2012).

English Heritage. 2010. Energy Efficiency in Historic Buildings. Early Cavity Walls. UK: English Heritage. Available :

http://www.climatechangeandyourhome.org.uk/live/insulating_walls_with_cavities.aspx

English Heritage. 2012. Listed Buildings. Available: http://www.englishheritage.org.uk/caring/listing/listed-buildings/

EST. 2004. Assessment of energy efficiency impact of Building Regulations compliance. BRE client report 219683, November 2004, Energy Saving Trust http://www.est.org.uk/partnership/uploads/documents/Houses_airtightness_report_Oct_04.pdf Eurobuild. 2012. Our supply chain: carbon footprint Version 1.1. Available http://www.eurobuilduk.co.uk/

Feist, W. 2012a. EnerPHit Certification: Criteria for Residential-Use Refurbished Buildings. Available http://www.passiv.de/en/03_certification/02_certification_buildings/04_enerphit/04_enerphit.h

Feist, W. 2012b. Passive House Planning Package Version 7 (2012). Passive House Institute, Darmstadt Germany. Availablee www.passivehouse.com 
Franchimon, F, 2009 Healthy Building Services for the 21st Century. PhD thesis PhD thesis, Eindhoven: Technische Universiteit Eindhoven.

Fraunhofer IBP, 2012. Press Release Adoption of Passive House building principles is accelerating worldwide. WUFI-Passive http://www.ibp.fraunhofer.de/en/Press/Press_releases/pm_06-092012_passivehouses.html

Fuehres, M., Isoliertechnik 5/96: Die Alternativen - wie gut sind ökologische Dämmstoffe wirklich? (Sonderdruck), Lambda Verlag, 1996,

Gellert, R. 2010a. Inorganic mineral materials for insulation in buildings. In: Hall, M. Materials for energy efficiency and thermal comfort in buildings. Oxford, Woodhead Publishing, pp. 193-228.

Gellert, R. 2010b. Natural fibre and fibre composite material for insulation in buildings. In: Hall, M. Materials for energy efficiency and thermal comfort in buildings. Oxford, Woodhead Publishing, pp. 229256.

Glaser H., 1959, Grafisches verfahren zur Untersuchung von Diffusionvorgänge, Kältetechnik, 10, p. 345-349 (in German)

Goodhew, S. and Griffiths, R. 2005. Sustainable Earth Walls to Meet the Building Regulations. In: Energy and Buildings, 2005, 37(5), pp. 451-459.

Green Building Store (GBS), 2010. The Denby Dale Passivhaus. Available http://www.denbydalepassivhaus.co.uk

HM Government. 2010a The Building Regulations. Approved Document Part L1B. Conservation of fuel and power in existing dwellings Available www.planningportal.gov.uk/uploads/br/BR_PDF_ADL1B_2010.pdf 
HM Government. 2010b The Building Regulations. Approved Document Part L1A. Conservation of fuel and power in new dwellings Available www.planningportal.gov.uk/uploads/br/BR_PDF_ADL1A_2010.pdf

Haus der Zukunft, 2000. Österreichisches Strohballennetzwerk, http://www.baubiologie.at/asbn/download.htm (last accessed on November 2011)

Hemke, O., 2009, Untersuchung der Konstruktionsweisen im Strohballenbau hinsichtlich ihres Wärmedämmverhaltens mit Hilfe der Thermografie, Freie wissenschaftliche Arbeit zur Erlangung des Grades eines Diplom-Ingenieurs an der Technischen Universität Berlin

Hens, H.,1990 Guidelines \& Practice vol.2. ecbcs.org. (Online) August 1990. http://www.ecbcs.org/docs/annex_14_guidelines_and_practice.pdf.

Hens, H., 2012 “Actual limits of HAM-modelling looking at problems encountered in practice; Part 1 : A short history of Heat, Air and Moisture modelling” in IBPSA News Vol. 22 Nr 2, ISSN 1993-8586, available on www. ibpsa.org

Hopfe, C.J., 2009. Uncertainty and sensitivity analysis in building performance simulation for decision support and design optimization, PhD thesis, Eindhoven: Technische Universiteit Eindhoven. (Copromot.: prof.dr.ir. J.L.M. Hensen \& dr. M.T.M Emmerich).

Hopfe, C.J. \& Hensen, J.L., 2011. Uncertainty analysis in building performance simulation for design support. Energy and Buildings, 43(10), pp.2798-2805.

House of Commons (2005). Housing: Building a Sustainable Future. First Report of Session 2004-05 Volume I. Environmental Audit Committee. Available: http://www.publications.parliament.uk/pa/cm200405/cmselect/cmenvaud/cmenvaud.htm 
IBP Fraunhofer Institute of Building Physics. 2010. WUFI Pro Training course material, delivered by Fraunhofer IBP at Cardiff University, Wales 8-9 9th $^{\text {th }} 2010$

Inbuilt and Davis Langdon. 2010. Study of hard to fill cavity walls in domestic dwellings in Great Britain. Hertfordshire: Inbuilt.

IPCC. 2000. IPCC Special Report on Emissions Scenarios. WG III of the IPCC. Cambridge: Cambridge University Press (2000)

Jenkin, G., Perry, M. and Prior M. 2007. The Climate of the United Kingdom and Recent Trends. UKCP08 Scientific Report. Met Office Hadley Centre, Exeter UK. December 2007. Available www.ukcip.org.uk

Killip, G. 2005. Built Fabric and Building Regulations. Background material F, 40\% House Project. Environmental Change Institute University of Oxford. March 2005. Available: http://www.eci.ox.ac.uk/research/energy/40house.php

Killip, G. 2008. Building a Greener Britain: Transforming the UK’s Existing Housing Stock. A report for the Federation of Master Builders. Environmental Change Institute, University of Oxford

Künzel, H., 1996 Zweischalige Außenwände mit Kerndämmung und Klinkerverblendung. wksb 37 (1996), p. 15-19.

Künzel, H., 2000. Moisture risk assessment of roof constructions by computer simulation in comparison to the standard Glaser-Method, international building physics conference, Eindhoven ,September 2000

Künzel, H. 2006. WUFI ${ }^{\circledR}$ PC-Program for calculating the coupled heat and moisture transfer in buildings. Fraunhofer Institute for Building Physics. Holzkirchen, Germany.

Künzel, H., Zirkelbach, D., 2011 Seminar in hygrothermics and WUFI application presented by Fraunhofer IBP, Cardiff University, and University of Nottingham, Dartington Hall 2011. 
Lazarus, N. 2002. BedZED: Toolkit Part I. A guide to construction materials for carbon neutral developments. Bioregional Development Group. Available http://www.bioregional.com/

Minergie. 2012. The Minergie Standard for Buildings. Available:

http://www.minergie.ch/publications.478.html

May, N. 2009. Breathability: Why the Kingspan White Paper is Seriously Misleading. (Online) Available at: http://www.natural-building.co.uk/PDF/Breathability-Matters-response-to-Kingspan.pdf

McCabe, J. (1993): Thermal Resistivity of Straw Bales for Construction (Master thesis), University of Arizona, Tucson

McLeod, R., 2007. Passivhaus Local House. MSc thesis, 2007 University of East London

McLeod, R. Hopfe, C.J., Rezgui, Y. 2012a. An investigation into recent proposals for a revised definition of zero carbon homes in the UK. Energy Policy (2012), http://dx.doi.org/10.1016/j.enpol.2012.02.066.

McLeod, R., Hopfe, C., Rezgui, Y., 2012b. A proposed method for generating high resolution current and future climate data for Passivhaus Design. Energy and Buildings (article in press) 2012

Morehead, J. 2010. Impact of climate variation in Ireland on the performance of passive and low energy projects. See the Light 2010: Building a Carbon-Free Future. Dublin 9 September 2010.

Muneer, T. 2004. Solar radiation and daylight models. Elservier Butterworth-Heinemann, Oxford. 2nd Ed. 2004. ISBN 0750659742

Munch-Andersen, J., Moller Andersen B., 2008. Straw Bale Houses- design and material properties, Danish Building and Urban research, available online on http://www.baubiologie.at/download/jma_slides_halmhuse.pdf

Murray, F.W. 1967. On the computation of saturation vapor pressure. J. Appl. Meteor. 6: 203-204. 
Natural Resources Canada (NRCAN). 2012. The Background of R 2000. available http://oee.nrcan.gc.ca/residential/new-homes/r-2000/3660

NHER report, 2005. National Homes Energy Rating organization, www.nher.co.uk

Norford, L., Socolow, R., Hsieh, E. Spadaro, G. 1994. Two-to-one discrepancy between measured and predicted performance in a 'low energy' office buiding: insights from a reconciliation based on the DOE2 model. Energy and Buildings, 21 pp 121-131

Office for Gas and Electricity Markets. 2011. Review of the third year of the Carbon Emissions Reduction Target (CERT). London: Office for Gas and Electricity Markets.

Olivier, D. 2001.Building In Ignorance, Demolishing Complacency: improving the energy performance of $21^{\text {st }}$ century homes. Report for the Energy Efficiency Advise service for Oxfordshire and the Association for the Conservation of Energy. Available at: www.ukace.org/.../ACE\%20Research\%20(2001-10)

Osbourn, D. 1985. Introduction to Building. London: Batsford Academic and Educational.

Olivier, D. 2001. Building in ignorance. Demolishing complacency: improving the energy performance of 21st century homes. Association for the Conservation of Energy/Energy Efficiency Advice Services for Oxfordshire http://www.ukace.org/pubs/reportfo/BuildIgn.pdf

Passive House Institute (PHI). 2010. EnerPHit Criteria for Residential-Use Refurbished Buildings.

Published by the Passive House Institute, Darmstadt, 17 Aug 2010

Passivhaus Trust (PHI), 2012 available on http://www.passivhaustrust.org.uk/projects/, last accessed 2012

Pfluger, R (2006). Solutions for Damp Protection in Internal Insulation. 10th International Passive House Conference Proceedings. 19-20 May 2006, Hanover,

Phillips, R., Blackmore, P., Anderson, J., Clift, M., Aguiló-Rullán, A., Pester, S., 2007. 
FB 17 - Micro wind turbines in urban environments: an assessment. IHS BRE Press, Watford. Available at: www.brepress.com

Pulimood TB, et al 2007. Epidemic asthma and the role of the fungal mold Alternaria alternata. Journal of Allergy and Clinical Immunology: 120(3); 610-617.

Quirouette, R.. 2004, Air pressure and the building envelope, available on http://www.cmhcschl.gc.ca/en/inpr/bude/himu/coedar/upload/Air-Pressure-and-the-Building-Envelope.pdf

Rawlins, F. 1984. The accuracy of estimates of daily global irradiation from sunshine records for the United Kingdom. Met. Mag.113, p187.

Remund, J. 2010. Meteonorm 6 Theory (available) http://www.meteonorm.com

Roels S., 2008, Experimental Analysis of Moisture Buffering, Final Report IEA-ECBCS Annex 41 'Whole Building Heat, Air, Moisture Response', ACCO, Leuven

Sanders, C., \& Phillipson,M.,2006. Review of Differences between Measured and Theoretical Energy Savings for Insulation Measures. Centre for Research on Indoor Climate and Health, Glasgow Caledonian University December 2006.

Seiders,D., Ahluwalia,G., Melman,S., Quint,R., Chaluvadi,A., Liang,M., Silverberg, A., Bechler, C., Jackson, J., 2007. Study of Life Expectancy of Home Components. Available at: www.nahb.org (Accessed February 21, 2011).

Shamash, M., 2012. Understanding future climate data from UKCP09 for weather data selection:

a methodology. CIBSE ASHRAE Technical Symposium, Imperial College, London UK - 18th and 19th April 2012

Smith, P. 2005. Architecture in a climate of change - A guide to sustainable design. London: Elseiver/Architectural Press 
Sutton, A., Black, D., Walker, P. 2011. Straw Bale: An Introduction to Low-Impact Building Materials. (Online) Available at: http://www.bre.co.uk/filelibrary/pdf/projects/low_impact_materials/IP15_11.pdf

Tetens, O., 1930. Uber einige meteorologische Begriffe. z. Geophys. 6:297-309

UK Parliament, 2008. Climate Change Act 2008. Available at:

http://www.legislation.gov.uk/ukpga/2008/27/contents (Accessed August 6, 2012).

WAG, 2004. Fuel Poverty in Wales, 2004: Evaluating the impact of energy price rises on fuel poverty.

Welsh Assembly Government, Department for Environment, Sustainability and Housing, September 2007

WBCSD, 2011, available at: www.wbcsd.org (Accessed June 2011).

Which?. 2011. Holes in insulation advise, finds Which? probe. (Online) Available at:

http://www.which.co.uk/news/2011/03/holes-in-insulation-advice-finds-which-probe-248617/ (Accessed 12 February 2012)

Winter, S., 2011. Greenhouse Gas Emissions in Federal Buildings. Available at: www.wbcsd.org/resources/greenhousegasemissions.php (Accessed June 2011)

Woloszyn, M., Rode, C., 2008. IEA ECBCS Annex 41 Final report - Modelling principles and common exercises.

WWF, 2011. Parliamentary Briefing - Zero Carbon Homes. World Wildlife Fund. Available assets.wwf.org.uk/.../microsoft_word_zero_carbon_homes_briefing

Zero Carbon Hub (ZCH), 2009a. Defining Zero Carbon Homes: 'Have Your Say' Report 2009, Available at: http://www.zerocarbonhub.org/resourcefiles/ZCH-HaveYourSay.pdf (Accessed August 4, 2010).

Zero Carbon Hub (ZCH), 2009b. Zero Carbon Hub Task Group: Defining a Fabric Energy Efficiency Standard for Zero Carbon Homes: executive summary. 2009. Available at: http://www.zerocarbonhub.org/resourcefiles/FEES_ExecSummary_15_3_10.pdf. 
Zero Carbon Hub (ZCH), 2011. Allowable Solutions for tomorrow’s new homes: towards a workable framework. Available at: http://www.zerocarbonhub.org/resourcefiles 